\title{
Corrigendum: Characterization of cmcp Gene as a Pathogenicity Factor of Ceratocystis manginecans
}

\author{
Zhiping Zhang ${ }^{1}$, Yingbin $\mathrm{Li}^{1}$, Laixin $\mathrm{Luo}^{1}$, Jianjun $\mathrm{Hao}^{2}$ and Jianqiang $\mathrm{Li}^{1 *}$ \\ ${ }^{1}$ College of Plant Protection/Beijing Key Laboratory of Seed Disease Testing and Control (BKL-SDTC), China Agricultural
} University, Beijing, China, ${ }^{2}$ School of Food and Agriculture, The University of Maine, Orono, ME, United States

Approved by: Frontiers Editorial Office Frontiers Media SA, Switzerland

${ }^{*}$ Correspondence: Jianqiang $L$

lijq231@cau.edu.cn

Specialty section

This article was submitted to Fungi and Their Interactions,

a section of the journal

Frontiers in Microbiology

Received: 15 August 2020

Accepted: 18 August 2020 Published: 18 September 2020

Citation:

Zhang Z, Li Y, Luo L, Hao J and Li J (2020) Corrigendum: Characterization

of cmcp Gene as a Pathogenicity Factor of Ceratocystis manginecans.

Front. Microbiol. 11:595238.

doi: 10.3389/fmicb.2020.595238

\section{A Corrigendum on}

Characterization of $\operatorname{cmcp}$ Gene as a Pathogenicity Factor of Ceratocystis manginecans

by Zhang, Z., Li, Y., Luo, L., Hao, J., and Li, J. (2020). Front. Microbiol. 11:1824. doi: $10.3389 /$ fmicb.2020.01824

In the original article, there was an error in the Abstract. The word "complemented" was misspelled as "complimented." A correction has been made to the Abstract. The corrected sentence appears below:

"A complemented mutant $(\Delta c m c p-C)$ was obtained by transforming $c m c p$ to $\Delta c m c p$."

The authors apologize for this error and state that this does not change the scientific conclusions of the article in any way. The original article has been updated.

Copyright $\odot 2020$ Zhang, Li, Luo, Hao and Li. This is an open-access article distributed under the terms of the Creative Commons Attribution License (CC BY). The use, distribution or reproduction in other forums is permitted, provided the original author(s) and the copyright owner(s) are credited and that the original publication in this journal is cited, in accordance with accepted academic practice. No use, distribution or reproduction is permitted which does not comply with these terms. 